\title{
A Study on Novel Corona Virus Disease (COVID-19)
}

\author{
Harsimran Singh ${ }^{1}$, Santosh Kumar ${ }^{2}$ and Rakesh Kumar ${ }^{3}$ \\ ${ }^{1}$ Department of Computer Science Engineering, ${ }^{2}$ Department of Mechanical Engineering, \\ ${ }^{1 \& 2}$ Chandigarh Group of Colleges, Landran, Mohali, Punjab, India \\ ${ }^{3}$ Research Scholar, Department of Mechanical Engineering, Chandigarh University, Mohali, Punjab, India \\ E-mail: santoshdgc@gmail.com
}

\begin{abstract}
COVID-19 is a global pandemic and life threatening virus that mainly influences the respiratory tract of mammals, consisting humans being. It was 1st isolated in 1937 from an infectious bronchitis virus in birds. Many years ago, scientists have investigated that corona virus can infect mice, horses, dogs, pigs, rats, cats, cattle and turkeys. This zoonotic virus was first identified from Wuhan City, China and presently increasing very rapidly. The world has confirmed 141,057,106 cases, which includes $3,015,043$ deaths and $793,484,083$ vaccine doses administered as per the WHO till 20th April, 2021. Hence the aim of this paper is to provide a detailed review of COVID-19 including their history, origin, characteristics, symptoms and impacts along with preventive measures to be taken to restrict the outbreak of this evil virus of on human life.
\end{abstract}

Keywords: Corona Virus, COVID-19, 2019-nCOV, SARS-CoV2, Symptoms, Transmission, Treatment, Preventions

\section{INTRODUCTION}

The initial stages of this pneumonia, the symptoms of SARS-CoV infection appeared but on Jan 7, this outburst was discovered as a new species of corona viruses [1]. This new species was then termed by World Health Organization (WHO) as 2019 novel corona virus (2019-nCoV). The origin of this virus is suspected to be the wet market or the Huanan seafood wholesale market which sell freshly slaughtered game animals. Recently, a public health emergency of international concern has been declared by the WHO. On an average, an infected person or even a mild ill person affects 2-3 persons, thus making this spread exponential [2]. In addition, this virus may stays on any surface for a maximum 3 days. It seems that the bats are the zoonotic origin of this virus. The size of this virus ranges from $60-140 \mathrm{~nm}$ and has a spike like projections which gives this virus a crown like appearance. From the literature it is found that SARS-CoV-2 has 4 structural proteins (S: Spike, E: Envelope, M: Membrane and N: Nucleocapsid proteins). The nucleocapsid proteins hold the RNA genome and spike, envelope and membrane proteins together create the viral envelope as shown in Fig. 1.

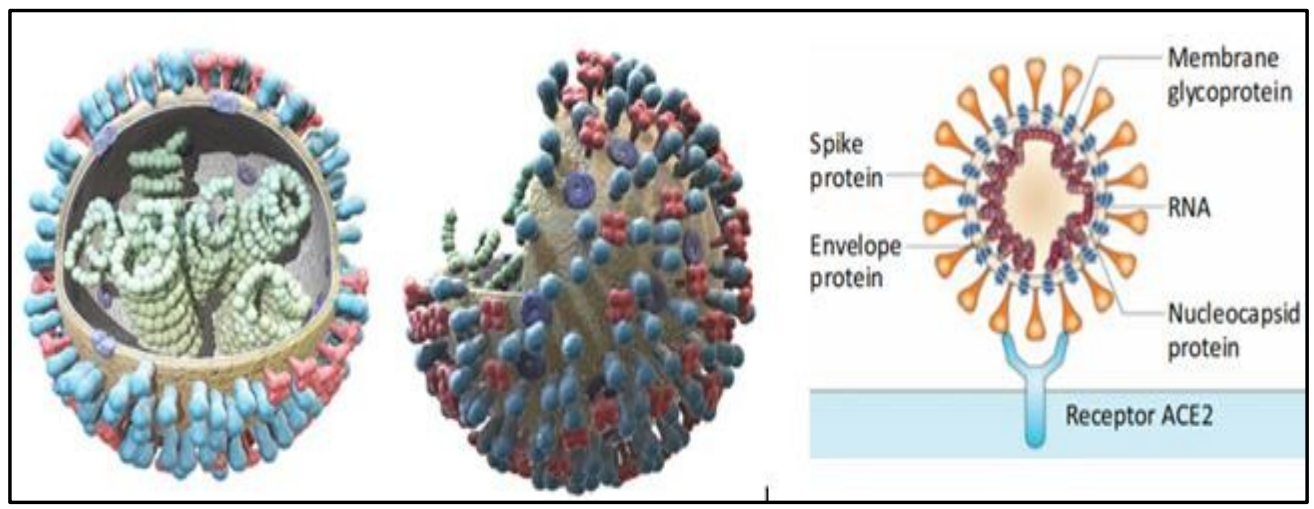

Fig. 1 Representations of corona virus structure \& viral receptor angiotensin converting enzyme-2 on the surface of host cell [3]

\section{HISTORY}

Tyrell and Bynoe described the first species of Corona virus in 1966 which was cultivated from the patients having common cold [4]. This 2019-nCoV is the seventh member of enveloped RNA corona virus (subgenus sarbeco virus, Ortho corona virinae sub family) [5].This outburst was fort the third time in several decades, after the SARS-CoV (severe acute respiratory syndrome corona virus) outburst of 2003 and MERS-Cov (Middle East respiratory syndrome corona virus) outburst of 2012 [6-10]. This 2019-nCoV show some features alike to SARS patients, such as epidemiological, clinical, laboratory and radiological features [11-13]. Wet markets show the connection of both the 2019-nCov and SARS-CoV outbursts where game animals and meat were sold. Two virus genomes (HKU-SZ002a and HKU-SZ-005b) revealed that this novel corona virus is more closely connected with those of batSLCoVZXC21 (NCBI Accession number MG772934) and bat-CoVZC45 (NCBI accession since number MG772933) [14]. 


\section{A. Origin}

The wet market or the Huanan Sea food market of Wuhan, the capital city of Hubei province became the origin of this zoonotic virus. This was made evident from the environmental samples taken from the market [15]. In late December 2019, many patients reported to the Wuhan hospital with severe pneumonia fun known cause. These patients were found to have a common subjection to the seafood market or any connection with the trade of the live animals with the market [16]. On $31^{\text {st }}$ December 2019, China reported about this outbreak to the World Health Organization and this food market was immediately order end to be shutdown. On $7^{\text {th }}$ January, WHO identified this corona virus, which has about $95 \%$ similarities with bat corona virus [16].

This new species also showed some symptoms of the 2013 out Burst of SARS-CoV. The human-human transmission was revealed by the innumerable rise of new patients which even do not have a contact with the sea-food market [17]. This transmission could occur either by direct contact with the infected one or through infected air droplets. This transmission is said to be most effective when there is a 1 meter's gap from the infected person whereas the maximum range to which this virus could spread is yet unclear [18].

\section{B. Characteristics / Sign \& Symptoms}

The symptoms of COVID-19 in general may be visible in two to fourteen days after getting exposed. This zoonotic corona virus causes severe respiratory diseases. This virus causes fever, cough, shortness of breath, acute respiratory distress syndrome, aches, pain in the chest, runny nose, bluish lips or face and sore throat [13]. Fever and cough are the most common symptoms. However, some people have also felt the loss of smell or taste. Also, this novel corona virus is found to affect more on older males, probably due to their weaker immune system [7]. SARS-CoV-2 virus causes the disease COVID-19, has the ability to replicate the cells of the lower respiratory tract [19]. This virus is transmitting by inhalation and by the contact with infected droplets. Its incubation period lies between 2-14 days [16]. Patients with cancer history are more expected to be attacked by COVID-
19. No availability of the basic and necessary medical services is the main risk for the cancer patients in this pandemic [20].

Y Liu made a report on the basic reproduction number (R0) which gives an idea about the spread of the disease. If the calculated value of R0 is greater than one, the infection spread is likely to increase and vice versa. This R0 concept indicates the risk of spread of the disease. This review article concluded the estimated value of mean, median and IQR were 3.28, 2.79 and 1.16 respectively which on comparison with WHO's estimate was pretty large enough [21]. J. Gao suggested that in the era of global widespread of this COVID-19, Chloroquine phosphate, which was earlier recommended for the treatment of malaria, is showing apparent efficacy against this COVID-19 so this could be included for the treatment of pneumonia caused by COVID-19[22].

\section{Global Spread}

Initially, it was believed that this COVID-19 would be constrained to the China only, but later it spread all around the globe by the movement of the mass. Now this virus is globally growing at a much faster pace, affecting over 100 countries within a few weeks. On an average, an infected person or even a mild ill person affects 2-3 persons, thus making this spread exponential [2]. The world has confirmed 141,057,106 cases, which includes 3,015,043 deaths as per the WHO till 20th April, 2021 [23]. S.Tian reported that $73.3 \%$ of the Beijing patients were from the Beijing itself while the $20.2 \%$ had come from Wuhan, but $89.1 \%$ of the Beijing's people were having a contact with the infected people of Wuhan [24].This reveals the largescale human-human transmission is possible globally. The estimated case fatality rate in Italy comes out to be $7.7 \%$, which is almost double than the first two week of the pandemic [25]. After few weeks, this rate exceeds than that of China also showing its ear-piercing symptoms and effects. Till now, 214 countries have been gripped by this COVID-19, among which USA, Brazil and Russia holds the top positions respectively. Table I gives the status of top 9 countries covid cases (confirmed cases, deaths, vaccine doses) till 20th April, 2021.

TABLE I REPRESENT THE COVID-19 STATUS OF TOP 9 COUNTRIES [23, 26]

\begin{tabular}{|c|l|c|c|c|}
\hline Sl.No. & Country & Confirmed cases & Deaths & Vaccine doses \\
\hline 1 & USA & $31,311,941$ & 561,616 & $202,553,704$ \\
\hline 2 & Brazil & $13,900,091$ & 371,678 & $32,394,085$ \\
\hline 3 & Russia & $4,710,690$ & 105,928 & $14,108,341$ \\
\hline 4 & UK & $4,387,824$ & 127,270 & $39,846,781$ \\
\hline 5 & Spain & $3,396,685$ & 76,882 & $11,598,499$ \\
\hline 6 & Italy & $3,870,131$ & 116,927 & $12,982,448$ \\
\hline 7 & Germany & $3,142,262$ & 79,914 & $18,284,633$ \\
\hline 8 & India & $3,870,131$ & 116,927 & $12,982,448$ \\
\hline 9 & Turkey & $4,268,447$ & 35,926 & $18,494,796$ \\
\hline
\end{tabular}


Transport has been affected to a great extent. All the services have been ceased such as import of various essential products such as iron and steel from the China [27]. This has affected the global economy to a great extent. The global economy is further affected by surfeit so various industries such as [28]. Surfeit to the travel industry, hospitality industry, sports industry, oil-dependent countries, and import-dependent countries, financial sectors such as banks, financial markets, event industry, entertainment industries, health sector and education sector. COVID-19 has become a pandemic, resulting into extensive spread in a few countries such as Italy, Iran, and South Korea and Japan [29, 30].So, the preparation of the vaccine is the only way of survival. Governments and industries should sell the vaccine at affordable price and not at the highest bids in order to save the lives of those who are at the heart of the outburst [2].

\section{Status of COVID-19 in India}

This zoonotic virus is exponentially spreading at a very fast rate all over the globe. It has created a pandemic situation worldwide. India was quick to notice the spread, danger and seriousness of this virus. This pandemic has increased the usage of masks and hand sanitizers which has led to the shortage of it for the Health and sanitary workers. How can the social workers provide service to a densely populated country like India even without having the basic necessities like masks and sanitizers? COVID-19 has locked people into their homes, thus creating a threatening situation outside. Almost countries have declared a situation of lockdown in their respective countries. Various video clips are circulating on the social media, creating the scene of panic among people. Due to this fear, India witnessed its first suicidal case on 12thFeb, 2020. The victim was from a village in Chittoor district of Andhra Pradesh [31]. India reported its first COVID-19 positive patient on 31st Jan, 2020. After that, Honorable Prime Minister, Shri Narendra Damodar Das Modi had taken immediate steps to curb it such as prevention of international passengers. After knowing the seriousness of the virus and its impact on other countries, the Indian Govt. announced 'Janta- curfew' i.e. a country Wide lock down at mid-night on 24 $4^{\text {th }}$ March, 2020. He ordered all the government offices to be closed for 21 days except the necessities like fire services, police and hospitals. In this pandemic situation, people are seen willingly showing their interest in following all the government policies such as that of isolation and quarantine as shown in Fig. 2.

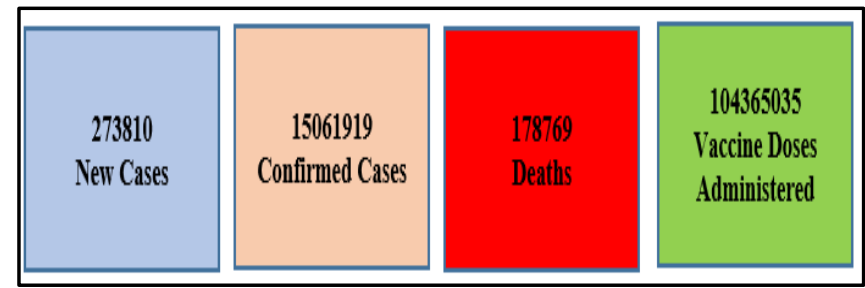

Fig. 2 Shows the COVID-19 pandemic data till 20th April, 2021in India [26]
The different region of India where this pandemic of COVID-19 is spread till 20th April 2021 is given in Table II.

TABLE II NUMBERS OF COVID -19 CASES) UP TO 20 ${ }^{\mathrm{TH}}$ APRIL, 2021 (TOP 36 COUNTRIES OF INDIA [32]

\begin{tabular}{|c|c|c|c|c|}
\hline $\begin{array}{l}\text { Sl. } \\
\text { No. }\end{array}$ & Name of States & $\begin{array}{l}\text { Total } \\
\text { Cases }\end{array}$ & $\begin{array}{l}\text { Total } \\
\text { Cured }\end{array}$ & $\begin{array}{l}\text { Total } \\
\text { deaths }\end{array}$ \\
\hline 1 & $\begin{array}{l}\text { Andaman \& } \\
\text { Nicobar }\end{array}$ & 145 & 5212 & 64 \\
\hline 2 & Andhra Pradesh & 48053 & 912510 & 7437 \\
\hline 3 & $\begin{array}{l}\text { Arunachal } \\
\text { Pradesh }\end{array}$ & 176 & 16820 & 56 \\
\hline 4 & Assam & 7663 & 217017 & 1142 \\
\hline 5 & Bihar & 49528 & 280286 & 1790 \\
\hline 6 & Chandigarh & 3804 & 30325 & 417 \\
\hline 7 & Chhattisgarh & 129000 & 423591 & 6083 \\
\hline 8 & $\begin{array}{l}\text { Dadra \&Nagar } \\
\text { Haveli }\end{array}$ & 1136 & 3962 & 4 \\
\hline 9 & Delhi & 76887 & 787898 & 12361 \\
\hline 10 & Goa & 7547 & 59705 & 900 \\
\hline 11 & Gujarat & 68754 & 341724 & 5494 \\
\hline 12 & Haryana & 45363 & 315002 & 3448 \\
\hline 13 & $\begin{array}{l}\text { Himachal } \\
\text { Pradesh }\end{array}$ & 9783 & 67084 & 1203 \\
\hline 14 & $\begin{array}{l}\text { Jammu \& } \\
\text { Kashmir }\end{array}$ & 12164 & 133981 & 2063 \\
\hline 15 & Jharkhand & 30477 & 135256 & 1502 \\
\hline 16 & Karnataka & 142103 & 1021250 & 13497 \\
\hline 17 & Kerala & 103327 & 1144791 & 4950 \\
\hline 18 & Ladakh & 1699 & 10474 & 133 \\
\hline 19 & Lakshadweep & 490 & 791 & 1 \\
\hline 20 & Madhya Pradesh & 74558 & 341783 & 4636 \\
\hline 21 & Maharashtra & 678198 & 3159240 & 60824 \\
\hline 22 & Manipur & 296 & 29102 & 377 \\
\hline 23 & Meghalaya & 754 & 14071 & 154 \\
\hline 24 & Mizoram & 437 & 4546 & 12 \\
\hline 25 & Nagaland & 189 & 12285 & 94 \\
\hline 26 & Odisha & 23118 & 347637 & 1948 \\
\hline 27 & Puducherry & 4692 & 42931 & 713 \\
\hline 28 & Punjab & 35311 & 261364 & 7985 \\
\hline 29 & Rajasthan & 76641 & 346739 & 3204 \\
\hline 30 & Sikkim & 404 & 6165 & 136 \\
\hline 31 & Tamil Nadu & 75116 & 914119 & 13157 \\
\hline 32 & Telengana & 42853 & 316650 & 1856 \\
\hline 33 & Tripura & 506 & 33194 & 394 \\
\hline 34 & Uttarakhand & 18864 & 105437 & 1892 \\
\hline 35 & Uttar Pradesh & 208523 & 661311 & 9997 \\
\hline 36 & West Bengal & 53418 & 604329 & 10606 \\
\hline Total & 2031977 & 102648 & 154761 & 1761 \\
\hline
\end{tabular}




\section{ZONES OF COVID-19}

On the basis of cumulative COVID-19 cases and their doubling rate, the Government of India divided the various districts into three zones as shown in Fig. 3.

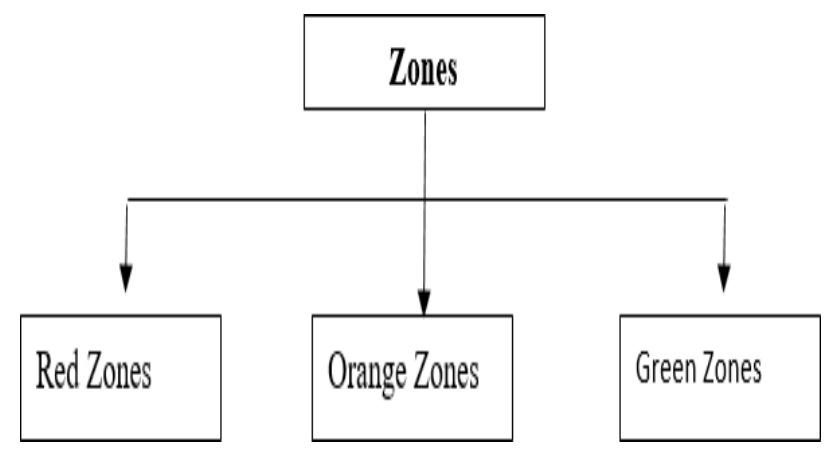

Fig. 3 Classification of zones [33]

A. Green Zone: A district is considered under green zone if there are no confirmed cases so far or there is no reported case since last 21 days in the district.

$B$. Red Zone: A district is considered under red zone if the district has large number of COVID- 19 (positive) cases or the district is under hotspot area.

C. Orange Zone: The intermediate zone between the green zone and red zone is considered as orange zone. The numbers of Indian districts per zone is given in Table III.

TABLE III NUMBER OF DISTRICT PER ZONE IN INDIA [33]

\begin{tabular}{|c|c|}
\hline Zones & District/zone \\
\hline Red zone & 130 \\
\hline Orange zone & 284 \\
\hline Green zone & 319 \\
\hline
\end{tabular}

D. Ray et al., [34] provides the detailed information about various recommendations for the lockdown. He suggested that there is a better chance of reducing the COVID-19 cases if this lockdown is implemented and utilized efficiently [34]. Labor class has also been adversely affected by this lockdown period. This period has forced the class to force fully migrate to their respective cities on their foot, after becoming complete jobless, with their families and especially children on their shoulders, almost half starved [35, 36]. Fear of isolation and fear of being quarantined are seen to be much powerful and dominating than the fear of the virus itself.

Several cases in India have been reported about the break out of people from the hospitals and various quarantined centers. This throws the light over the fact that people have trust issues for the Indian medical facilities and public health system [37]. In a country like India where we have around 350 million social media users, social media is a well-known platform for spreading social awareness and public health facts from various sections of the country. In this epidemic situation, people are misusing this platform by spreading various fake news, about the coronavirus-19 [38]. Even before the first case in India was confirmed, masks and sanitizers were stocked out from the country. This shortage affected many medical staff members and frontline healthcare workers. Also, fake claims of this virus to be airborne added fuel to the fire [39].

\section{EFFECTS OF COVID-19 IN INDIA}

This viral outburst has created havoc all around the globe. It has forced the mass to stay in their Effects of COVID-19 are illustrated in Fig.4.

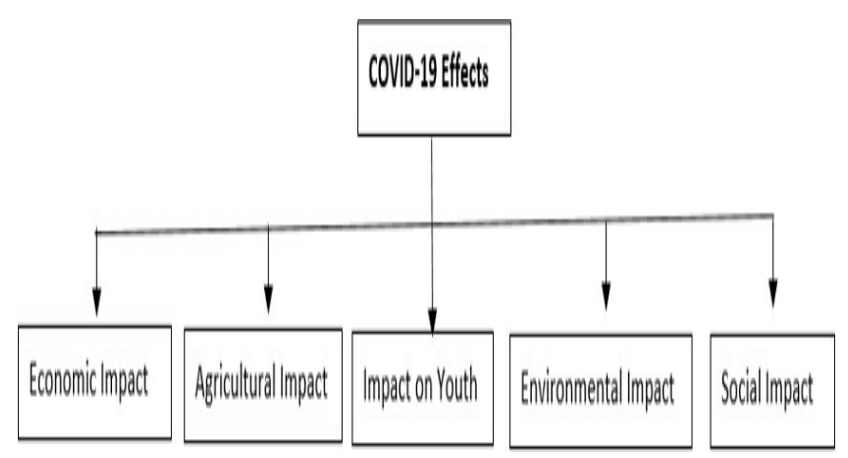

Fig. 4 Effects of COVID-19 [40]

\section{A. Impact on Economy}

The Covid-19 has highly affected the different sources of supply and affects the global economy. This results in losses in international and national business. There are limitations of travelling one when tested, mainly when they are taking international visits [41]. However, the different impacts of Covid-19 are as follow.

\section{B. Rise in Unemployment}

Thousand countries have slowed down their manufacturing of the products, result in rise of unemployment. As per the international labor organization report it is estimated that globally greater than 25 million jobs would be threatened owing to the spread of corona virus. Even UK, US \& most of the Asian and European countries have begun to register huge job losses leading to significant rise in unemployment rate which disturb the mental health. On $18^{\text {th }}$ march 2020 , the International Labor Organization's press reported a decline of 24.7 million jobs as a high scenario and 5.3 million jobs lost as a low scenario. However, in the high scenario, the worldwide unemployment rate would rise from $4.9 \%$ to $5.6 \%$, whereas in case of the low scenario the unemployment would increase to $5.08 \%$. This results in increase in suicides a case which is approximately 9570 per year for high scenario and it is nearly 2135 per year for low scenario. [42].

\section{Collapse of Indian Rupee}

The Rupee has touched its all-time lowest value as the US Dollar has jumped to 103.80. The Economic shut down has become a COVID-19. 


\section{Impact on Agriculture}

Non availability of labor is peppering various agricultural activities throughout the nation, especially in the north-west India where wheat and pulses are harvested.

1. Decline in prices for various agricultural crops.

2. Problems are also being faced by the distributers due to the nation-wide lockdown.

\section{E. Impact on Youth}

1. Morethanonebillionyouthisnownotgoingtoschoolsandun iversitiesafterthispandemic and postponement of examinations.

2. Loss of education for youth as online education system is now going up to the mark especially in India.

3. The loss of Job opportunities for youth due to this pandemic, Rise in competition in every field for youth as this pandemic will affect the future scope of jobs for at least 6-7 years [41, 43].

\section{F. Impact of Environment}

On contrary to the impacts, environment is having the positive impact of this widespread disease. Some of them are: Decrease in the Air Pollution due to cancellation of various travels.

1. There is a $25 \%$ reduction in emission of carbon in the early lockdown period, as reported by the Centre for Research on Energy and Clean Air [44, 45].

2. It has also helped in decreasing the global warming.

3. S. Sharma also reported about the improve dairy quality in India, due to this pandemic situation [46].

\section{G. Social Impact}

Masses had been forced to stay at their homes during this out-burst of corona virus. People were asked to make a distance from their relatives and friends. This has made a complete cut-off from social contact.

\section{PREVENTIVE MEASURES}

In absence of vaccine- quarantine, social distancing and isolation of infected ones for at least 14days is necessary [14]. Chloroquine and hydroxychloroquine are showing some curing aspects for this COVID-19 which was earlier used to cure malaria [47]. As an individual also, some safety steps are to be taken to fight against this virus. Some of them are:

1. Sanitize your hands regularly at-least after every 23hours.

2. Avoid gathering and going to crowded places.

3. Always wear a mask before going to some crowded place.

4. Cover your mouth while sneezing and coughing.
5. Follow the government rules of social distancing and isolation techniques.'

6. Avoid close contact with people who are sick.

7. Avoid touching your eyes, nose and mouth.

8. Practice social distancing by putting proper space other and yourself.

9. Wash hands often with soap and water for at least twenty sec. [47].

\section{RECENT STUDIES ON COVID-19}

Distinct authors have recently studies the various effects of COVID-19. Some of the studies are described below:

Liu et al., [48] reviewed the historical development of COVID-19 and its clinical and epidemic properties. The authors also highlights the distinct strategies utilized for the purpose of prevention and control of this serious disease in China. This would be beneficial for other countries respond to the outbreak. Cui et al., [49] re-evaluated the pharmacokinetic characteristics, clinical efficiency, precautionary use and mechanism of the drug "Hydroxychloroquine" (HCQ). The author also emphasized the effectiveness of the HCQ against the CoVID-19 with sufficient evidence. Anastasiou, et al., [50] discussed the literature search performed using MEDLINE, Cochrane and EMBASE Library from January 2020 to April 2020 in order to assess in vitro data of current COVID-19 therapies. The author spotlighted the assuring nature of the drugs like chloroquine, hydroxychloroquine, remdesivir, teicoplanin, lopinavir, emetine, nitazoxanide, ivermectin and homoharringtonine. Qi Z. et al., [51] reappraises the salient points of epidemiological and demographic characteristics and provides the updated significant findings about the COVID19. The author underlined the novel insights and the pathogenic molecular mechanism related to the 2019-nCoV. Costanzoet al. [52] reconsidered that the experimental antiviral therapies combined with the government control measures and the availability of ICU beds in hospitals could play a great role in combating with the COVID-19. Shahab et al., [53] claimed the use of Triazavirin (2-methylsulfanyl-6-nitro [1, 2, 4] triazolo [5,1-c] $[1,2,4]$ triazin-7(4H)-one, TZV) for potential application against the COVID-19. The author reviewed the complete molecular study, oscillator strengths and excitation energies of this antiviral drug. This drug could act potentially against the 2019-nCoV. Antonelli et al., [54] revised the virology, clinical aspects and mode of transmission of this Covid-19. The author emphasized on various therapies and prevention techniques to resist the covid-19.Kuca et al., [55] reviewed the transmission routes, diseases associated, clinical specimen study, incubation period and symptoms of the novel corona virus covid-19. Basak et al., [56] re-evaluated the SIR mathematical model and its derivation which could resist the spread of COVID-19. The author also emphasized on the use of peptide vaccines using computer-aided vaccine design (CAVD).

However, several authors explained current approaches and strategies for resisting COVID-19. In addition, clinics, epidemiology along with preventive measure of COVID-19 
are also reviewed. They also used X-ray image to differentiate COVID-19 with other chest diseases. The effective ways that combat COVID -19 is also discussed. Some authors also reported some chemical used by China to combat COVID-19 [57-68].

Currently most of the advanced technologies are utilized in the development of vaccine such as production platforms, vectors and precise antigen scissoring. There is no approved vaccine and sufficient data on production process is available to prevent from corona virus. However, clinical development has to start ab-initio. A proper animal model having similar human ACE-2 receptors need to be recognized. In addition, continuous assessment of induced complication, toxicity and safety studies need to be evaluated. Fig. 5 represent the clinical development ladder initiating from current good manufacturing practice production through clinical trials to licensure, production at large scale, marketing, administration and finally the evaluation of the immunity. However, the evaluation of immunity developed by vaccine is generally a long process. But, due to continuous efforts among government agencies, production companies, regulatory authorities and WHO this process would be completed within 3 to 15 months from now.

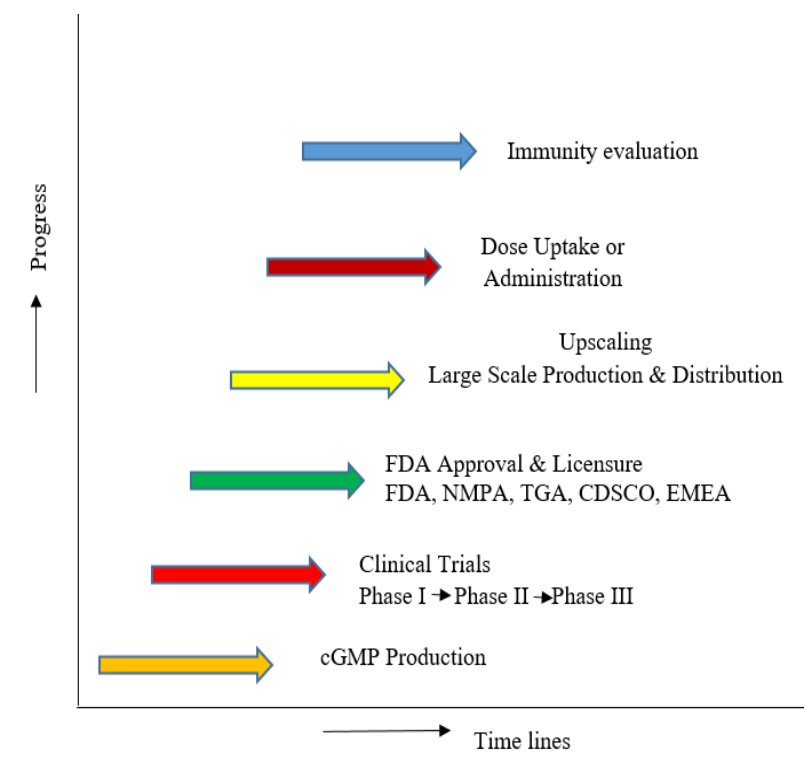

Fig. 5 Clinical Development Ladder of New Vaccines against COVID-19 [69]

Where, FDA- Food and Drug Administration; NMPANational Medical Products Administration, China; TGATherapeuticGoodsAdministration;CDSCOCentralDrugsStand ardControlOrganization, India; EMEA- Europe, the Middle East \& Africa.

\section{STUDY ON COVID-19 VACCINE}

A fundamental piece of building up any immunization is to guarantee that known and hypothetical dangers are distinguished, measured, and weighed against expected advantages.
As of July 2, 2020, the overall SARS-CoV-2 immunization scene incorporates 158 antibody competitors, out of which 135 are in the preclinical or the exploratory phase of their turn of events. At present, mRNA-1273 (Moderna), Ad5-nCoV (CanSinoBiologicals), INO-4800 (Inovio, Inc.), LV-SMENPDC, Pathogen-explicit aAPC (ShinzenGeno-Immune Medical Institute), and ChAdOx1 (University of Oxford) have entered the stage I/II clinical preliminaries (WHO, 2020) [70].A few organizations are creating nucleic corrosive based antibodies, including Moderna, BioNTech/Pfizer, CureVac (mRNAbased), and Inovio (DNA-based). DNA-and m RNA based antibodies can be produced rapidly based on viral grouping, which permits a quick pathway to the center [71]. Even though conclusions of antibody security what's more adequacy will be founded on grounded necessities of administrative experts in the United States, the European Union, and other worldwide areas and the ability to create and convey a huge number of antibody dosages have been sped up to deal with the pandemic. Accordingly, numerous individuals might be immunized before longer-term follow-up is conceivable. Also, COVID-19 antibodies will be controlled to more established people who are credulous to this microbe, though information about antibody reactions in this age bunch has regularly come from antibodies intended to help to melt away resistance [72].

The author [73] surveyed the well-being and viability of two $30-\mu \mathrm{g}$ dosages of BNT162b2, directed intramuscularly 21 days separated, as contrasted and fake treatment. Grown-ups 16 years old or more seasoned who were sound or had stable ongoing ailments, including yet not restricted to human immunodeficiency infection (HIV), hepatitis B infection, or hepatitis $\mathrm{C}$ infection disease, were qualified for investment in the preliminary. A total of 43,548 members went through randomization, from those 43,448 got infusions: 21,720 with BNT162b2 and 21,728 with fake treatment. There were 8 instances of Corona virus in beginning at any rate 7 days after the second portion among members allocated to get BNT162b2 and 162 cases among those allotted to fake treatment. BNT162b2 was 95\% successful in forestalling Covid-19 (95\% dependable stretch, 90.3 to 97.6). Comparable antibody adequacy (for the most part 90 to $100 \%$ ) was seen across subgroups characterized by age, sex, race, identity, benchmark weight list, and the presence of coinciding conditions.

The author [74] enlightened that the $S$ protein is the significant objective for COVID-19 vaccine advancement, essentially dependent on the elicitation of infection-killing antibodies as the safe correspond to immunization assurance. The current status of COVID-19 immunization advancement incorporates, I) three-stage I immunization competitors, ii) 11 preclinical antibody competitors and iii) 26 exploration stage immunization applicants. The S quality successions of SARS-CoV-2 segregates have a $93.1 \%$ nucleotide arrangement character to the Rhinolophusaffinis bat Covid RaTG13. 


\section{CONCLUSION}

December, 2019 was known to be atrocious for human mankind as in late December; the seafood market of Wuhan province of China sowed the seeds of a new species of corona viruses which proved to be deadly for whole mankind because of its mortality rate and speed of transmission. World Health Organization (WHO) named this new specie as CoVID-19 and declared a public health emergency of international concern. Bats are considered to be the zoonotic origin of as this virus $s$ how $s$ much biological similarity with that of the bats. Fever and cough are seen to be the common symptoms of this virus. The incubation period of this virus is found to lie between 3-14 days. The world has confirmed 141,057,106 cases, which includes 3,015,043 deaths and 793,484,083 vaccine doses administered as per the WHO till 20th April, 2021.Out of this, India confirms 1, 15, 14,331 cases with 1 , 59,370 deaths. Figures mentioned above reveals the seriousness of the situation. The COVID-19 has an adverse impact one economic, Environmental and social. This paper provides the current situation of COVID-19 in India in detail along with preventive measure. This virus is spreading in human very fast. However, distinct scientists and research group is working to search anti corona virus vaccine for the treatment of this serious virus. So, till the preparation of a suitable vaccine for this, we must follow the Government policies issued by the WHO to fight against this pandemic situation and more importantly "to survive".

\section{REFERENCES}

[1] R. Dandona, "Nanshanchen- epidemiological and clinical characteristics of 99 cases of 2019 novel coronavirus pneumonia in Wuhan, China: A Descriptive Study,” Vol. 6736, No. 20, pp. 302117, 2020. DOI: http://doi.org/10.1016/S0140.

[2] B. Gates, "Responding to Covid-19: a once-in-a-century pandemic" The New England Journal of Medicine, Vol. 382, No. 18, pp. 16771679, 2020. DOI: https://doi.org/10.1056/nejmp2003762.

[3] R. Varala and H. Bollikolla, "nCovid-19 in 2020: From Despair to hope", Coronaviruses, Vol. 1, pp. 9-12, 2020. DOI:10.274/2666796701999200621202839.

[4] T. P. Velavan and C. G. Meyer, "The Covid-19 epidemic", Tropical Medicine and International Health, Vol. 25, No. 3, pp. 278-280, 2020. DOI: https://dx.doi.org/10.1111\%2Ftmi.13383

[5] K. V. Holmes and L. Enjuane, "The SARS Coronavirus: A postgenomic era," Science, Vol. 300, pp. 1377-1378, 2013. DOI: 10.1126/science.1086418.

[6] K. H. Chan, L. L. Poon and V. C. C. Cheng, et al., "Detection of SARS coronavirus in patients with suspected SARS," Emerg Infect Dis., Vol. 10, No. 2, pp. 294-299, 2004. DOI: 10.3201/eid1002.030610.

[7] J. F. C. MD, et al., "A familial cluster of pneumonia associated with the 2019 novel Rotavirus indicating person-to-person transmission: a study of a family cluster Author links open overlay panel," Journal of Lancet, Vol. 395, pp. 514-523, 2020.

[8] E. I. Azhar, S. A. El-Kafrawy and S. A. Farraj et al., "Evidence for camel-to-human transmission of MERS coronavirus," N. Engl. J. Med., Vol. 26370, No. 26, pp. 2499-505, 2014. DOI: 10.1056/NEJMoa1401505.

[9] S. Perlman, "Another Decade, another Coronavirus," New England Journal of Medicine, Vol. 382, pp. 760-762, 2020. DOI: 10.1056/NEJMe2001126

[10] W. J. Guan, "Clinical characteristics of 2019 novel coronavirus infection in china," New England Journal of Medicine, Vol. 2, pp.123-129, 2020. DOI: 10.1056/NEJMoa2002032
[11] J. S. M. Peris, S. T. Lai and L. L. Poon, et al., "Coronavirus as a possible cause of severe acute respiratory syndrome,” Lanet, Vol. 361, pp.1319-1325, 2003. DOI: 10.1016/s0140-6736(03)13077-2

[12] J. S. Peiris, C. M. Chu and V.C. Cheng, et al., "Clinical progression and viral load in a community outbreak of coronavirus-associated SARS pneumonia: a prospective study,” Lancet, Vol. 361, pp.176772, 2003.

[13] V. C. Cheng, S. K. Lau, P. C. Woo and K.Y. Yuen, "Severe acute respiratory syndrome coronavirus as an agent of emerging and remerging infection," ClinMicrobiol Rev., Vol. 20, pp. 660-694, 2007.

[14] Hussain, "Covid-19: India imposes lockdown for 21 days and cases rise,” BMJ, Vol. 368, pp. 109-119, 2020. DOI: https://doi.org/10.1136/bmj.m1251

[15] O. Ozdemir, "Coronavirus Disease 2019 (COVID-19): Diagnosis and Management (Narrative Review)," Erciyes Med J 2020, Vol. 42, No. 3, pp. 1-6, 2020. DOI: 10.14744/etd.2020.99836

[16] T. Singhal, "A Review of Coronavirus Disease-2019 (COVID-19)", Indian J Pediatr, Vol. 87, pp. 281-286, 2020. DOI: https://doi.org/10.1007/s12098-020-03263-6.

[17] C. Huang, Y. Wang and $\mathrm{X}$. Li, et al., "Clinical features of patients infected with 2019 novel coronavirus in Wuhan, China.", Lancet. Vol. 395, pp. 497-506, 2020.

[18] A. Repici, R. Maselli, M. Colombo, R. Gabbiadini, M. Spadaccini, A. Anderloni, S. Carrara, A. Fugazza, M. Di Leo, P. AlessiaGaltieri, G. Pellegatta, E. Chiara Ferrara, E. Azzolini and M. Lagioia, "Coronavirus (COVID-19) outbreak: what the department of endoscopy should know”, GastrointestEndosc, pp. 30245-5, 2020. DOI: 10.1016/j.gie.2020.03.019.

[19] B. Hu, H. Guo and P. Zhou, et al., Characteristics of SARS-CoV-2 and COVID-19. Nat Rev Microbiol, Vol. 19, pp. 141-154, 2021. DOI: https://doi.org/10.1038/s41579-020-00459-7

[20] E. Pigozzi,D. Tregnago, L. Costa, J. Insolda, E. Turati, et al., "Psychological impact of Covid-19 pandemic on oncological patients: A survey in Northern Italy”, PLOS ONE, Vol. 16, No. 3, e0248714, 2021. DOI: https://doi.org/10.1371/journal.pone.0248714

[21] Y. Liu, A. A. Gayle, A. Wilder-Smith and J.Rocklov, "The reproductive number of COVID-19 is higher compared to SARS coronavirus,” Journal of travel medicine, pp. 1-4, 2020.

[22] J. Gao, Z. Tian and X. Yang, "Breakthrough: Chloroquine phosphate has shown apparent efficacy in treatment of COVID-19 associated pneumonia in clinical studies”, Biosci Trends 2020, Vol. 14, No. 1, pp. 72-78, 2020. DOI: 10.5582/bst.2020.01047.

[23] WHO Coronavirus (Covid-19) dashboard, [Online]. Available: https://covid19.who.int/

[24] S. Tian, N. Hu, J. Lou, K. Chen, X. Kang, Z. Xiang, H. Chen, D. Wang, N. Liu, D. Liu, G. Chen, Y. Zhang, D. Li, J. Li, H. Lian, S. Niu, L. Zhang and J. Zhang, "Characteristics of COVID-19 infection in Beijing”, National Library of Medicine, Vol. 80, No. 4, pp. 401406. 2020. DOI: https://doi.org/10.1016/j.jinf.2020.02.018

[25] M. Lazzerini, G. Putoto, "COVID-19 in Italy: momentous decisions and many uncertainties," National Library of Medicine, 2020, Vol. 8, No. 5, pp. 640-650. DOI: https://doi.org/10.1016/S2214109X(20)30110-8.

[26] [Online]. Available: https://www.mygov.in/covid-19

[27] D. Roy, S. Tripathy, S. Kumar Kar, N. Sharma, S. Kumar Verma and V. Kaushal, "Study of knowledge, attitude, anxiety and perceived mental healthcare need in Indian population during COVID-19 pandemic,” Asian Journal of Psychiatry, 2020. DOI: https://doi.org/10.1016/j.ajp.2020.102083

[28] H. Singh, S. Kumar and R. Kumar, "Impact of COVID-19 on economy: A Critical Review", I Managers-Journal on Humanities and Social Science, Vol. 1, No. 3, 2020. [Online]. Available: https://imanagerpublications.com/article/17632/35.

[29] R. M. Anderson, "How will the country-based mitigation measures influence the course of the COVID-19 epidemic," The Lancet, Vol. 395, pp. 931-934, 2020. DOI: https://doi.org/10.1016/S01406736(20)30567-5

[30] "India under COVID-19 lockdown" The lancet, Vol. 395, 2020, DOI: https://dx.doi.org/10.1016\%2FS0140-6736(20)30938-7

[31] K. Goyal et al., "Fear of COVID 2019: First suicidal case in India", Asian J Psychiat, Vol. 49, pp.146-155, 2020. DOI: 10.1016/j.ajp.2020.101989. Epub 2020 Feb 27.

[32] [Online]. Available: https://www.mohfw.gov.in/\# 
[33] R. Saravana and S. Manisha, "Unintended Consequences of Lockdowns: COVID-19 and the Shadow Pandemic" NBER Working Paper No. 27562, JEL No. I15,I18, J12,J16,O15, 2020.

[34] D. R, M. Salvatore, R. Bhattacharyya, L. Wang, S. Mohammed, S. Purkayastha and B. Mukherjee, "Predictions, role of interventions and effects of a historic national lockdown in India's Response to the COVID-19 pandemic: data science call to arms," Harvard data science, pp. 123-133, 2020. DOI: https://doi.org/10.1101/2020.04. 15.20067256

[35] T. J. Hwang, K. Rabheru, C. Peisah, W. Reichman, and M. Ikeda, "Loneliness and social isolation during the COVID-19 pandemic", Int Psychogeriatr, Vol. 1, pp. 1-4, 2020. DOI: https://dx.doi.org/10.1017 \%2FS1041610220000988

[36] P. Aggarwal, M. Singh, K. Kumar and A. Bansal, "Socio- Medical and Hospitality Impacts of SARS-Cov-2 in the Indian Context", International Journal of Advanced Science and Technology, Vol. 29, No. 11, pp. 2163-2173, 2020.

[37] P. Chetterje, "Gaps in India's preparedness for COVID-19 control”, The Lancet, 2020. DOI: https://doi.org/10.1016/S1473-3099(20) 30300-5

[38] H. Sahni and H. Sharma, "Role of Social Media during the COVID19 Pandemic: Beneficial, Destructive or Reconstructive”, IJAM, Vol. 6, No. 2, pp. 70-75, 2020.

[39] A. B. Kadam and S. R. Atre - "Negative impact of social media panic during the COVID-19 outbreak in India "- DOI: https://doi.org/10.1093/jtm/taaa057

[40] A. Haleem, M. Javaid and R. Vaishya, "Effects of COVID-19 pandemic in daily life", Current Medicine Research and Practice. 2020. DOI: $10.1016 /$ j.cmrp.2020.03.011

[41] M. Chinazzi, J.T. Davis and M. Ajelli, et al., "The effect of travel restrictions on the spread of the 2019 novel coronavirus (COVID-19) outbreak."Science.2020. DOI: https:// doi.org/10.1126/science.aba9757.

[42] W. Kawohl, C. Nordt, "COVID-19, Unemployment and Suicides", Correspondance, Vol. 1, pp. 1-2, 2020 DOI: https://doi.org/10.1016/ S2215-0366,

[43] A. Kumar, S. Sharma, and R. Kumar, "Importance of Universal Human Values in Education System: A Critical Review”, I Manager's Journal of Humanities \& Social Science, 2020, Vol. 1, No. 2, pp. 45-55.

[44] H. Jindal, S. Kumar, and R. Kumar, "Environmental Pollution and its Impact on Public Health: A Critical Review", Asian Review of Mechanical Engineering, Vol. 9, No. 1, pp. 11-18, 2020.

[45] L. Snehal, and S. Pratibha, "Indirect impact of COVID-19 on environment: A brief study in Indian context”, Environmental Research, Vol. 188, pp. 109807, 2020. DOI: https://doi.org/10.1016/ j.envres.2020.109807

[46] S. Sharma, M. Zhang, Anshika, J. Gao, H. Zhang and Sri H. Kota, "Effect of restricted emissions during COVID-19 on air quality in India," Science of The Total Environment, Vol. 728, 2020. DOI: https://doi.org/10.1016/j.scitotenv.2020.138878.

[47] P. Colson, J.M. Rolain, J.C. Lagier, P. Brouqui and D. Raoult, "Chloroquine and Hydroxychloroquine as available weapons to fight COVID-19,” Int J Antimicrob Agents, Vol. 55, No. 4, pp. 105932, 2020.

[48] N-N. Liu, J-C. Tan, J. Li, S. Li, Y. Cai and H. Wang, "COVID-19 Pandemic: Experiences in China and Implications for its Prevention and Treatment Worldwide”, Current Cancer Drug Targets, Vol. 20, No. 1, 2020. DOI: https://doi.org/10.2174/15680096206662004 14151419.

[49] C. Cui, S. Tu, V. S. J. En, X. Li, X. Yao, H. Li and D. Liu, "Review on the clinical pharmacology of hydroxychloroquine sulfate for the treatment of COVID-19”, Current Drug Metabolism, Vol. 21, No. 1, 2020. DOI: https://doi.org/10.2174/1389200221666200610172929

[50] J.A. Anastasiou, I. Eleftheriadou, A. Tentolouris, D. Tsilingiris and N. Tentolouris, "In Vitro Data of Current Therapies for SARS-CoV2”, Current Medicinal Chemistry, Vol. 27, pp. 4542, 2020. DOI: https://doi.org/10.2174/0929867327666200513075430

[51] Z. Qi and Y. Yu, "Epidemiological Features of the 2019 Novel Coronavirus Outbreak in China", Current Topics in Medicinal Chemistry, Vol. 20, pp. 1137, 2020. DOI: https://doi.org/10.2174/1 568026620999200511094117

[52] M. Costanzo, M. A. R. De Giglio and G. N. Roviello, "SARS-CoV-2: Recent Reports on Antiviral Therapies Based on Lopinavir/
Ritonavir, Darunavir/Umifenovir, Hydroxychloroquine, Remdesivir, Favipiravir and other Drugs for the Treatment of the New Coronavirus”, Current Medicinal Chemistry, Vol. 27, pp. 4536, 2020. https://doi.org/10.2174/0929867327666200416131117

[53] S. Shahab and M. Sheikhi, "Triazavirin - Potential Inhibitor for 2019nCoV Coronavirus M Protease: A DFT Study”, Current Molecular Medicine, Vol. 20, pp. 1, 2020. DOI: https://doi.org/10.2174/156 6524020666200521075848

[54] A. Antonelli, G. Elia, S. M. Ferrari, R. Foddis, S. De Marco, A. Cristaudo and P. Fallahi, "The Covid-19, Epidemiology, Clinic and Prevention", Current Genomics, Vol. 21, pp 1, 2020. DOI: https://doi.org/10.2174/1389202921999200427133052

[55] K. Kuca, "The 2019 Novel Coronavirus (COVID-19) Outbreak in China and World: A New Lesson for Public Health System”, Letters in Drug Design \& Discovery, Vol. 17, No. 1, 2020.

[56] S.C. Basak, S. Majumdar, M. Vracko, A. Nandy and A. Bhattacharjee, "A Generic Computer-Assisted Four-Pronged Approach for the Management of Emerging Global Pathogens: Some Comments on COVID-19", Current Computer-Aided Drug Design, Vol. 16: 1, 2020. DOI: https://doi.org/10.2174/1573409916999200 316102548

[57] D. Sivaraman, P. S. Pradeep, S. SundarManoharan, C. RamachandraBhat, K. V. Leela and V. Venugopal, "Current Strategies and Approaches in Combating SARS-CoV-2 Virus that Causes COVID-19", Letters in Drug Design \& Discovery, Vol. 17, No. 672, 2020. DOI: https://doi.org/10.2174/1570180817052004 03092546.

[58] A. Antonelli, G. Elia, S. M. Ferrari, R. Foddis, S. De Marco, A. Cristaudo and P. Fallahi, "The Covid-19, Epidemiology, Clinic and Prevention”, Current Genomics, Vol. 21, No. 1, 2020. DOI: https:/doi.org/10.2174/1389202921999200427133052.

[59] S. Albahli, "A Deep Neural Network to Distinguish COVID-19 from other Chest Diseases using X-ray Images”, Current Medical Imaging, Vol. 16, No. 1, 2020. DOI: https://doi.org/10.2174/157340561 6666200604163954.

[60] G. H. Lushington, "Perspective on the COVID-19 Coronavirus Outbreak”, Combinatorial Chemistry \& High Throughput Screening, Vol. 23, No. 90, 2020. DOI: https://doi.org/10.2174/138620732302200406130010.

[61] T. Serseg, K. Benarous and M. Yousfi, "Hispidin and Lepidine E: Two Natural Compounds and Folic Acid as Potential Inhibitors of 2019-novel Coronavirus Main Protease (2019- nCoVMpro), Molecular Docking and SAR Study”, Current Computer-Aided Drug Design, Vol. 16, No. 1, 2020. DOI: https://doi.org/10.2174/157340 9916666200422075440.

[62] A. P. Peter, C. K. Wayne, P. L. Show and T. C. Ling, "Potential Pathway that Could Treat Coronaviruses (COVID-19)", Current Biochemical Engineering, Vol. 6, No. 3, 2020. DOI: https://doi.org/10.2174/2212711906999200228100507

[63] I. Gentile and L. Abenavoli, "COVID-19: Perspectives on the Potential Novel Global Threat”, Reviews on Recent Clinical Trials, Vol. 15, No. 84, $2020 . \quad$ DOI: https://doi.org/10.2174/1574887115999200228100745.

[64] S. Kumar, Poonam and B. Rathi, "Coronavirus Disease COVID-19: A New Threat to Public Health", Current Topics in Medicinal Chemistry Vol. 20, No. 599, 2020. DOI: https://doi.org/10.2174/1568026620999200305144319

[65] W. Liu, H.L. Zhu and Y. Duan, "Effective Chemicals against Novel Coronavirus (COVID-19) in China”, Current Topics in Medicinal Chemistry, Vol. 20, No. 603, 2020. DOI: https://doi.org/10.2174/156 8026620999200305145032.

[66] A. K. Banerjee and N. Arora, "Coronavirus Disease (COVID-19) Pandemic: A Race Against Time”, Current Topics in Medicinal Chemistry, Vol. 20, No. 1, 2020. DOI: https://doi.org/10.2174/1568026620999200413145654

[67] H. Jindal, D. Kumar, Ishika, S. Kumar, and R. Kumar, "Role of Artificial Intelligence in Distinct Sector: A Study”, Asian Journal of Computer Science and Technology, Vol. 10, No. 1, pp. 1-12, 2021.

[68] K. Kuca, "The 2019 Novel Coronavirus (COVID-19) Outbreak in China and World: A New Lesson for Public Health System”, Letters in Drug Design \& Discovery, Vol. 17, No. 1, 2020. DOI: https://doi.org/10.2174/1570180817999200317145125. 
[69] A.H. Banday, S.A. Shah and S. J. Ajaz, "Potential Immunotherapy against SARS-CoV-2: Strategy and Status”, Coronaviruses, Vol. 1, pp. 23-31, 2020.

[70] S. PreetKaur and V. Gupta, "COVID-19 Vaccine: A comprehensive status report," Virus Research, Vol. 288, No. 198114, 2020. DOI: 10.1016/j.virusres.2020.198114.

[71] C. Lawrence, R. M. John, S. F. Anthony and S. Francis Collins, "A strategic approach to COVID-19 vaccine R\&D," Science,Vol. 368, No. 6494, pp. 948-950, 2020. DOI: 10.1126/science.abc5312

[72] B. F. Haynes, L. Corey and P. Fernandes et al., "Prospects for a safe COVID-19 vaccine," Science Translational Medicine, Vol. 12, No. 568, 2020. DOI: 10.1126/scitranslmed.abe0948
[73] F. P. Polack, M. D. Stephen and J. Thomas et al., "Safety and Efficacy of the BNT162b2 mRNA Covid-19 Vaccine", The New England Journal of Medicine, Vol. 383, pp. 2603-2615, 2020. DOI: 10.1056/NEJMoa2034577

[74] Wu and Suh-Chin, "Progress and Concept for COVID-19 Vaccine Development.” Biotechnology, Vol. 15, No. 6, 2020. DOI: 10.1002/biot.202000147. 